\title{
Old Bazaar and People Skills development after the 1990s in the City of Kruja
}

\author{
Dr. Manjola Xhaferri \\ University "Aleksander Moisiu" Durres, Albania. \\ Email:mxhaferri@yahoo.com
}

\section{Doi:10.5901/ajis.2014.v3n2p233}

\section{Abstract}

This paper aims to analyze the issues which are intended to show the continuity of tradition Albanian masterful focusing primarily on traditional handicrafts of the region of Kruja involved and art of this city. An important impetus has been especially large -scale fact that cultural tourism has taken, which bore the desire and interest to address the reactivation of some of the traditional to vocational order can be placed at the service of current developments. It is of interest that the only preserved Kruja shopping, with all the traditional features and therefore it offers optimal conditions, not only to activate, but also for trade, tourism here has since achieved great development dimensions. We note that currently this shopping skills alongside traditional products continue to exercise their crafts, marketed and imported products. Without denying the right of traders to sell these goods, I think that domestic production should have priority and should dominate in the traditional market town, where you left each visitor a choice of international and local actors. In this study I focused mainly on handcraft made by the women of this province and the women of the surrounding villages, mainly based on some form of work as are: works of woolen, linen works, silk works, especially works cotton. Skills exercised by them were intended to meet the needs of the family less for the market. While men in most work to sell goods within the province, but also in more distant markets. Men usually work consisted of working metal to stone, wood, etc., whose products serve not only for the family but also to trade them. This study will serve to further deepen the knowledge about the various artistic works of this province and the preservation of this tradition to generations to come.

Keywords: Bazaar, People, Skills, City, Kruja

\section{History of the Town Kruja Bazaar}

If we make an overview of Kruja Bazaar understood that he has a history of ancient establishment that has served not only as a trade center, but also as a place where they develop different exercisable workmanship. This is proven by the many sources written by foreign authors and the home. A portion of the old bazaar authors Kruja have called " the uncanny", here Degrand Frenchman can mention in his "Souvenirs de la Haut Albanie" published in Paris in 1901, the Old Bazaar of Kruja or " Derenxhiku». According to this author Kruja Bazaar is a treasure which is intertwined with the history of its beauty.

Another author is also named Hahn scholar who tries to give a version of this bazaar creation. According to his statement "Bazaar of Kruja, which consists of a narrow street of shops, partially covered, leading to the castle, old makes an impression that they seem to not have been any change since the time of Skanderbeg". So, by the time Hahn Skandrbegane main contenders for authorship is complete .

Also the author of the article " Market - age Kruja City", published in the journal - archive " Light " ( A year ago V , N II , bloated 1933 , page 47 ), Zef Arapi, referring to a statement by name Krutani Kruja Hysejn Yahya Kovaci, says the same thing.

Quote: " the pilgrim in Krue mrrijmen has one market account with the old system, from his interesting type, compels you to stop and ask me about his story .

Kruja say market and today we are presented with the narrow alleys shelter of Things, has been linked to the great gate of the castle, the provisions shows that the order has Skanderbeg it brave people and his army t'wander freely without being hampered by the doors enemies cruel centuries".

While the history of Kruja lovers L. Bajo Gjirokastra Shopping hypothesises that this characteristic is far ahead of the XV century. According to him, the bazaar begins with the construction of the castle that is already in the V - VI century, with the increase of population and economic activity of their social, especially during VI - VIII centuries later with the return of Kruja important episcopal center, in the ninth century. Quivers grow further in the XII century and beginning of the thirteenth century, where it became the center of the state of Arber (1119 - 1216), especially in XIII - XV centuries, 
as the center of Topiasve to 1425 years .

Also known scholar Ziya Shkodra in his " guild XV - XX century Albanian " pages 292-293, mentions several components of this bazaar .Certainly these hypothesis given by different authors seniority characteristic of Kruja Bazaar, always remain open. All of the above authors link Kruja Bazaar legendary history of this city, mainly with the heroic period Skanderbeg. And the times and people always say this document and vibrant monument to life, notwithstanding the different version.

\section{Handicraft Bazaar of Kruja}

Kruja Bazaar characteristic, even today continues to be very beautiful, more glamorous and exciting. As in previous periods where early traders were also the merchant manufacturer, some of these craftsmen today continue this tradition fanatically. Kruja Bazaar stretched on both sides of the road starting from the city center to the castle women, numbered before burning up on March 7, 1944 about 200 stores. This has two verses Bargain shopping in west - east direction, among them a paving roads with ditches to drain the water.

From the shopping function has had three types of stores:

- Shop for Artisan paper

- Shop Trading

- Shop traders resting for recreation but also foreign and domestic tourists

Shops were out front with Tarab ( boards that close the front, but later was with shutter).

As we stated earlier that 7:03 .1944 burned more than half the starting shopping part of town close to the mosque Varos. After World War II the remaining stores (less than half the Derexhik), were mainly of bread baking shops, cafes, barbers, shoemakers, etc. Private trade was banned after the dictatorial state, some shops were closed, others served as state commerce stores. These stores remaining after incineration was old and some of them began to crumble. But the state in 1968, on the occasion of the 500th anniversary of the death of Skanderbeg, made reconstruction of several shops, declaring Kruja Bazaar Monument of Culture. With the advent of democracy after 1990 or stores owners took their lands and their activities again, previous or others. Today almost all the shops are newly built and by projects of the Institute of Cultural Monuments. Focusing on popular professions Kruja after 90 years, the organization of them took a different form from previous periods, especially that of the second half of the twentieth century As I mentioned above that in communist period focused on state roads by creating production cooperatives, which are labeled with the term " Handicraft " by setting different craft units. In the 90 s due to the demolition of structures that favor their development and lack of visits by foreign tourists, we went in a different way based organization that private initiative. Trend at this time was that of finding a private road for sale and some to vocational revival even in private facilities, mainly in households. This transition led to the destruction of part of craftsmen and the survival of some other products mainly carpets, copper, wood and iron. Obviously the small size of the guaranteed market curbed sales. Having made a close study of the old bazaar of Kruja, through free interview with ordinary citizens, merchants and master different, but also through the survey shows that $30 \%$ of products and goods sold, handled by different master professional while $70 \%$ of goods imported from other countries of the Orient, as China, Turkey, to India. So for the organization of Kruja Bazaar stores today operates 64 stores registered as a small business. These are labeled with the name " SYVENIER " and are organized in the following form:

- 10 stores are equipped with goods that are made and marketed by relying on the cultural tradition of this city .

- 54 other stores merchandise trade come entirely from imports. These people call shops mixed goods stores .

To supply 54 stores two traders interested have made their monopoly job.

Among the shops that produce and trade goods to local traditions ( of the city) are

- Store workers fez

- woodworking shop working people

- Store iron working people

- Store the working people rugs

- Store embroiderers

- Store folk costumes

- watchmaker's shop ( remontier)

- repair shop for antique silver

In stores this shopping there as is the collection of antiques ( old buildings ) that are used across different families of rural citizens. They are collected by different people and sold in shopping .With the start of the transition period in the 
90s and before that was reactivated workmanship was of the workers' fez. It started operations in 1993. The workmanship of the old inherited over generations. Guni family remember who started this masterfully in 1920 ( inside the shopping ).

Among the leading masters of this family can mention Hysen Guni who has worked 40 years in the company 's Artistic. After 90 years he turned this skill into private business, or small business that provides income for his family. On the basis of an interview done with Mr. Guni he shows not only the processes of making the skill but also how difficult it is to maintain this tradition.

Among the works that he performs are:

- fez

- slippers

- Generations of men and women etc.

To exercise this skill is very important quality of raw materials is wool . According to Mr. Guni this case they provide Debar ( the Castle of Doda ), and later worked in the craft, which carried slippers, belts and various types fez, in the Albanian Center, North and South. Also works well for this master Kosovo fez. According to the realization of his thesis is an initiative fez difficult and tedious, that spends a lot of time and that profit is not very satisfactory. To work a fez by this master take at least two hours. He works together with his son and has two centers work at home and another one inside the shopping in the same store where does the selling. This master works well for messages that come from other provinces, Kosovo and Albania as Dibra, Shkodra, Tirana, Elbasan, etc. But his goods ordered by dealers folk costumes .

Besides fez, this master work even slippers and required more generations of residents of the highlands of Kruja. Generally the works of this master are quite liked by foreign tourists but also by Kosovars. However he stresses that seeing tedious work that requires this mastery, profit is scarce. After 2005 onwards, decreased demand for these goods. This has come as a result of entering the market of imported goods at prices which are much cheaper but have poor quality. In terms of continuity of this tradition is the master showing skeptical noting that if there is a market selling these goods very quickly tradition of practicing this craft, will be only a memory.

Wood Working: After 90 years as well as other professions that passed as a private initiative, especially after 1995. A master at Kruja voice work in wood is Asllan Lika, who works with a particular passion accomplishing specific objects artistic value. He realizes paintings carved in wood, so craft, with its domestic reasons of tradition, inspired by figures. Among the main works were those with the portrait of Mother Teresa, Skanderbeg, eagle, flag, etc. The sword of Skanderbeg .

Generally this mastery exercised in household environments and citizens krutanë order they marched traders and sold in the market. Besides paintings realized with pirografi, household appliances work well as doors, windows, tables, chairs, etc. These goods are highly demanded by locals from different visitors. Another workmanship that work with professionalism is that of making the iron. Even this craft is inherited through generations. Unlike other skills that were nationalized under the communist system, the maker of Iron exercised their skill independently, but there were those who exercised organized profession. This cleverly continued to work without interruption as 90 years before and afterwards. The activity of the iron work is enhanced especially after 2000 , as a result of numerous requests within the country.

Among the main products of iron working are:

- handrail

- railing

- gates

- doors

- shade (in beaten iron, etc.).

Production of iron constituted one of the most lucrative professions in this province. Among families with working name for Kruja iron was that of craftsmen. This is a mastery that work in household environments, and mostly custom. After 90 years, the masters of iron masterful work began to use more sophisticated tools, which entered the industrial equipment, which not only increased the amount of production, but also the quality. Raw material required for mastery imported from Italy, Germany, etc. In terms of continuity of this skill, as many versions of Iron working people, they are optimistic for this craft which will be increased and that of heritage preservation. Mastery of carpet working people. After the dissolution of Enterprises artistic workmanship began developing it privately. The first store was opened in 2004. It made the work processes and sales .

Seamstresses carry several kinds of items such as:

- Carpets

- Tapestry 
- carpets

- paths etc.

The master began to be reactivated later ( in 2004 ) due to lack of demand for domestic market and for export.Looking closely works of these masters not only impressed but also postpone buying something. Interviews are made direct to the store employees, about the mode of production and the completion time of an object, they are expressed, "Work tapestry carpets, wallpaper and rugs is not hard work, but it makes difficult work that our lack of market - sales", because this is the only source of livelihood for these workers. For working carpets and rugs streets today currently operate three such stores with some workers and each store has an owner. For this activity the best known are these entrepreneurs:

- Flamur Tabaku (no worker employed 4)

- Sali Maja (force 6)

- Fadil Rama (2 workers)

All employees are former employee of the firm, Artistic, belonging to a generation over 40 years, and are highly qualified and professional in their craft. Take raw materials from South merchants. Greater demand from these stores of foreign tourists, who during a visit to make Kruja Old Bazaar, listening to the pitter-patter jahu Tez, stop, and watch in awe of these women handyman work, and buy something. The demand for these products in these stores is also the home visitors. A longing for these women is the workmanship generations inherit. However they are more pessimistic about the fact that today's generation is not interested in extending this functionality and artistry. On the other hand they suffer the competition of imported goods, which are even cheaper. Even one of the women workers voiced phrase "who will work after we die ", this term has a meaning, which is directly linked to weakening of the operation of this tradition.

Mastery of embroidery before ' 90 developed under Artistic undertaking. After this period was reduced to a single store. The establishment of this store was in 1995, where embroider not only within the trading facilities but also the family. The shop owner collects these works and trades in store. These works sold well in the vicinity of the Castle, from sole traders. Among the major works carried out this mastery are:

- tablecloth

- Curtains based on the old tradition just could

- different types CENTRE

- cushion slipcover

- Complete sheets for quilts etc.

Bedding and curtains are embroidered with the sewing machine, a work that is done by the masters women. Except realized embroidery machine manually ( with needle). The workmanship is quite demanding dowry in place especially for girls. These works are liked by foreign tourists. Besides various embroidery, in this shop marketed different textile works, made by women of Kruja, Shkodra, Preza, etc.

Has recently begun to flourish Costume popular. This cleverly began work in 2005. Opened several shops where costumes are made and sold, as required by various individuals, mainly by Albanian refugees in different countries, but also from various artistic groups worked:

- Men's Suits

- costumes for women

- Children's Costumes

Masters of the mentioned today are:

- Idriz Cela ( and his wife ).

- Fatos Lleshi ( and his wife ).

- Lulzim Kasmi ( and his wife ).

Their women serve men while sewing and embroidery as traders. The raw material is imported from the orjentit countries like Turkey, China, Pakistan and Iran , mainly are:

- Drapery cashmere wool, velvet, Atlas,

- thin fabric ( marble)

- materials used for decoration as thymine, beads etc.

Mainly sought more artistic groups, but also from any foreign tourist.

Besides the above mentioned skills to another he started coming workmanship was Rectifier Hours (Remontier ) or regulatory. This craft has been old and is inherited through generations. As laborers work as watchmakers have had previous innings today. This is not a very profitable workmanship, but some families have lived with this craft. The master continues to be exercised in the bazaar, but there is great variety, as before. Another master who conducts business in 
the bazaar of Kruja is repair:

Antique jeweler. Today there is only one store. From 1975 until now the master of Elbasan Hamdi exercises, initially employed in the enterprise services Kruja, after 90 years in private business. It deals with the repair of swords, pistols, objects of worship, but also typewriters. Even after 90 years he has continued to deal with this trade, because there is still demand steadily. All this skill works made by hand. The master, the National Institute of Culture has given the right to exercise the profession. He now restores old items of silver, gold, and other metals, such as swords, pistols, etc. cult objects. Mr. Elbasan in terms of continuity of this tradition says that work keeps alive the craft. If there was work to exercise craft tradition is not lost, otherwise, everything fades. Recent years old Bazaar of Kruja, opened two stores that have accumulated old buildings, which are used in households, which collected from different persons. A part of Kruja citizens call hooligans.

After 1990, several persons went through the family as well as within the Kruja and piling into the surrounding ancient artifacts. Most of these families in the absence of recognition of these treasuries fell prey to the extortionists. These people collect items such as artworks in wood ( rural and urban facilities), ceramics, metal (jewelry, various ornaments, copper, container objects, coins, etc. , etc. All these objects they collected and seeing their real value pulled in the market recently, and sell 30 times of what they buy. Even many people who have sold their goods to the extortionists watch their artwork sold at unrealistically high.

Besides these we said above, in the old bazaar of Kruja has also shops that deal with the collection of old antique coins which create different collections from the earliest periods to the present day .

Similarly there are a philately shop ( postal stamp collector ).

Before 1990 in the old bazaar also exist maker of moccasins, leather working, who have exercised their activity on the basis of market requirements and sneezing. Currently they work outside the shopping center, somewhere on the outskirts of the city in the northeast, for which there is demand from Kruja mountain areas. Kruja is working and another that produces artistic plastic shoes for dancers, and for daily use at home ( mostly cow leather ), which is known as Kruja small business and supplies manufactured goods, private shops in Kruja, Tirana, Durres, etc. Through these works, continues to maintain popular traditions of this region. Meanwhile workmanship such as that of leather working people, working people the tin, it's making the mud, etc., then ceased to exist 90s. Today families living with income from these skills are completely removed from the profession. One question that I have done that, if the market was selling secure this craftsmanship, will return to practice this profession. With just a brief response directed, if the dead back from the grave is. The significance of this answer lies in the lack of a successor generation of this craft.

In woodcarving worked once before 90 years: wooden bowls, wooden spoons, clogs or sandals, etc., which thereafter was not produced anymore. Maybe these products passed in other provinces or in suburban areas. Besides those mentioned above, there are also other Mastery no longer functioning, but their gap filled with imported goods cheaper and not qualitative. I regret, while the stones glide Kruja Bazaar:

When will be given to the reactivation of these skills?

I wonder how many masters exist today in this city?

Maybe it will come naturally when again this shopping day will buzz the roar from the work of masters of Kruja. I believe that the very development of cultural tourism will feel this need .

\section{Conclusions and Recommendations}

In analyzing issues which are intended to show the continuity of tradition Albanian masterful focusing primarily on traditional handicrafts of the province including and art Kruja Kruja .An important impetus has been especially large -scale fact that cultural tourism has taken, which bore the desire and interest to address the reactivation of some of the traditional to vocational order can be placed at the service of current developments. It is of interest that the only preserved Kruja shopping, with all the traditional features and therefore it offers optimal conditions, not only activated, but also for trade , tourism here has since achieved great development dimensions. We note that currently this shopping skills alongside traditional products continue to exercise their crafts, marketed and imported products . Without denying the right of traders to sell these goods , I think that domestic production should have priority and should dominate in the traditional market town, where you left each visitor a choice of international and local actors.

In this study I focused mainly on handcraft made by the women of this province and the women of the surrounding villages, mainly based on some form of work as are : works of woolen, linen works, silk works, especially works cotton .

According to archaeological evidence some master exercised in this known to the ancients. How old is considered work on the vessels of clay, as it were : the bulbs for water , for milk jugs and many other serving utensils to prepare food 
. A part of the skills practiced by some women by men . In general, women develop their activity in household indoor environments .

Skills exercised by them were intended to meet the needs of the family less for the market. While men in most work to sell goods within the province, but also in more distant markets .

Men usually work consisted of working metal to stone, wood, etc. , whose products serve not only for the family but also to trade them . This study will serve to further deepen the knowledge of different artistic works of this province and the preservation of this tradition to generations to come.

\section{Ilustrative photo taken from Kruja Bazaar}
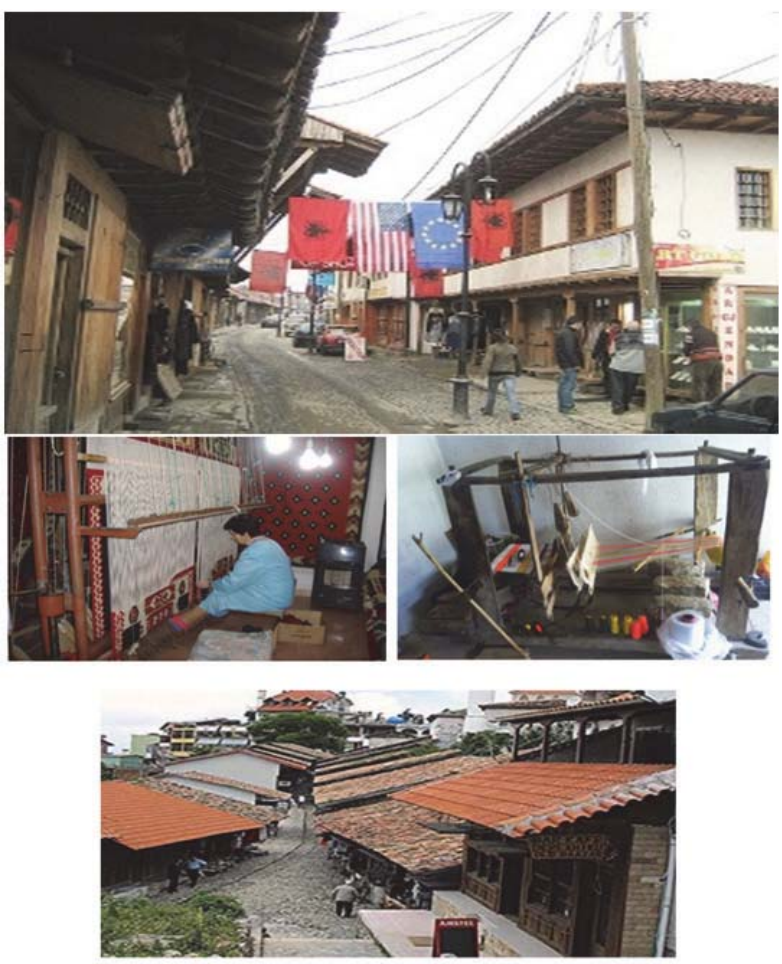

\section{Short references in the tex}

Degrand Frenchman (1901); Zef Arapi (1933); Ziya Shkodra (1973);

\section{References}

Arapi Zef : (1933) " Market - age Kruja City " published in the journal - archive " SOLO " A year ago V , No. II. Adka Stilian (1975) " Historical Information " Monuments of Culture 1 - Tirana.

Albanian Popular Art, " works in wool loom ", p , 1-8, Publishing House " November 8 " , Tirana 1977.

Bajo , Luan :( 1967 ) " Skanderbeg Kruja " Tirana, p. 14-25.

Bihiku , Iqbal :( 1985) " embroidery and city folk dresses " , Albanian Enografia , 14 - Tirana.

Bulletin , Tirana University . 1958, 3 - Kruja p. 45-63.

Bulletin , University of Tirana, 1963,2 - Medieval Cemetery p. 3-67.

Degrand , F , (1901) " Souvenirs de la Haut Albanie ", published in Paris.

Disha Muharram : (1973), writing in the newspaper " Galway " , " new carpet weavers " , p . 4 , Tirana , July - December , Friday, July 20.

Frasheri, Gjergj : (1986) " Archaeological Conservation Kruja Castle " , monuments , 1 - Tirana, p , 35-49

Frasheri, Gjergj (1989) " Rocky Kreshta Protection Kruja Castle ", monuments , 2 - Tirana , p , 35-51. 
Monuments, Culture in Albania, Tirana , 1970 , 1 - " Castle of Kruja " , p . 87-101.

Monuments, Culture in Albania, Tirana, 1975 , p . 92-93.

Magazine , " Illyria " Tirana , 1980 , V , II , " Zgerdhesh Kruja " , p , 195-213 .

Magazine , " Illyria " Tirana, 1983 , V , II , " Kruje - Daula " , p , 264-266

Magazine, " Illyria " Tirana, 1987, V , I, " Kruja - Daula " , p, 203-214 .

Magazine, " Illyria " Tirana, 1989 , V , I, " Danja " , p , 241-250.

Magazine, " Kruja " Publication of City Hall, " Problem integrating Bazaar Peculiar " , p . 5 , year II , No. 6 , June 2004

Magazine, " Kruja " Publication of City Hall , " Kruja " Capital " spiritual Albanian Nation " f, 1, year , l, December , 2003.

Newspaper , " Galway ", January - December , article " Artistic Enterprise Kruja " f, 6 , Friday, Jan. 23 Tirana , 1987.

Newspaper , "Galway ", January - December , article " Statistics facts and figures " , f , 5 , dated , January 30, 1987.

Newspaper, " Galway " , January - December, article " Kruja Tekstiliere works " , f , 3 , 23 March 1988.

Onuzi , Aferdita : (1985) " The fabrics of silk and cotton in the Center and North Coast ", Albanian Ethnology , 14 - Tirana.

Struga, Gezim : (1989) " Protecting the rocky ridge of the Kruja Castle ", monuments, 2 - Tirana, p . 35-51.

Shkodra, Ziya :( 1973) " Albanian guild XV - XX century " RP Academy of Sciences of Albania in Nis Press Printing Company " Mihal Duri ", Tirana.

Shkodra , Ziya : (1985) " Albanian Town in the Renaissance period ," Light Publishing House , March. 
